\title{
Measuring the Entrepreneurship Characteristics and Its Impact on Entrepreneurial Intentions
}

\author{
Khairi Mohamed Omar \\ College of Administrative Science, Applied Science University, Manama, Kingdom of Bahrain \\ Email: thebestuum@yahoo.com
}

How to cite this paper: Omar, K. M. (2021). Measuring the Entrepreneurship Characteristics and Its Impact on Entrepreneurial Intentions. Open Journal of Business and Management, 9, 672-687. https://doi.org/10.4236/ojbm.2021.92035

Received: January 18, 2021

Accepted: March 15, 2021

Published: March 18, 2021

Copyright $\odot 2021$ by author(s) and Scientific Research Publishing Inc. This work is licensed under the Creative Commons Attribution International License (CC BY 4.0).

http://creativecommons.org/licenses/by/4.0/

\begin{abstract}
Scientific progress, technology and industrial development in addition to globalization have allowed for the flow of a large amount of market information (capital information, investment information, labor, goods and services information etc.), which has resulted in intense competition increasing day by day because of the rapid technological developments, communication technology, electronic commerce and economic blocs. This has led to the industrial development of goods and services at an accelerated pace, and the development of business organizations under the pressure of intense competition and they must search for sophisticated strategies to stay in the market and the performance of economic and social tasks entrusted to it, and be able to compete and then expand in the markets locally and internationally. Entrepreneurship is one of the main topics in the economies of both developed and developing countries. Effective entrepreneurship contributes to economic development and the information era has led to dramatic changes in the work environment. Participation and technology have resulted in a faster pace the competition between local and international institutions, which works in an innovative way to disseminate information to produce products and provide new services to customers. The information era is also an incentive to restore successful traditional work patterns. As a result, innovation has become the main factor in separating leading institutions at all local, regional, and international levels. This paper aimed at measuring the characteristics of Entrepreneurship among postgraduate students from different universities in the Kingdom of Bahrain and its impact on entrepreneurship characteristics. A conceptual framework has been presented for a better understanding of the entrepreneurship characteristics topic which formed the basis for the topic under study. Using a quantitative method, 1000 questionnaires were distributed to target respondents comprising of international and local graduate students studying/graduated from different universities in the Kingdom of Bahrain. The
\end{abstract}


responses collected were 930 completed questionnaires representing a 93\% percent response rate. The data were analyzed using Smart PLS version 3. The findings indicate that entrepreneurship characteristics of the post-graduate students are a valid construct in predicting entrepreneurial intentions.

\section{Keywords}

Entrepreneurship, Characteristics, Entrepreneurial Intentions, Kingdom of Bahrain

\section{Introduction}

One of the most up-raising sources in this globalization era is the entrepreneurship eco-system which has been confirmed to have a major role in a transitional economy (OECD, 2013; de Beurs, 2018; Fuerlinger, Fandl, \& Funke, 2015; Malecki, 2018; Poon, Zhou, \& Chan, 2009). Culture, personal characteristics as well as transformation leaders and students become an entrepreneur minded thinking which is a very challenging job. Organizations and countries start to urge their teaching institutions to set up a way of teaching and develop people entrepreneurship programs. No wonder, it is the new era where what you do have today of natural resources start to decay and alternatives are many unseen, therefor, entrepreneurship could be a new potential resource and asset. These institutions however, have started to implement the new way of their style of teaching and the already start to produce entrepreneurs which according to Sloan School of Management (2009), leaded entrepreneurship business school, around 25,800 companies founded by Sloan School of Management (MIT) alumni entrepreneurs since they start their program (Roberts \& Eesley, 2009). These 25,800 active companies employ approximately 3.3 million people and generate annual world sales of two trillion, creating the equivalent of the eleventh-largest economy in the world.

Fayolle \& Gailly (2004) respectively in the USA and France, draw a clear picture about the entrepreneurship phenomenon evolution. In relation to this development, some practical and research issues emerged. Among these researches, the entrepreneurship topic teaching and assessment programs are probably one of the most critical questions in today's world education system to be considered. Very often, entrepreneurship teaching programs are launched within universities with a strong involvement of the local political and economic environment. These partners are therefore waiting for concrete results, through the creation of start-ups and/or the creation of new jobs by people having been educated and taught through the entrepreneurship teaching programs. Under these particular conditions, the assessment of the entrepreneurship teaching programs/courses takes into account a few indicators and mainly those we have just mentioned.

As the globe's market has become increasingly competitive and sophisticated 
in its post-reform era, an interesting question arises: How do local state corporatism, managerial networks, and market-oriented behaviors relate to business performance in Bahrain's enterprises? The recent development seems to suggest that the influence of local community governments on the performance of enterprises in Bahrain has substantially diminished, particularly in the face of the privatization process embarked by the new government promising strategies plans. In saying so, this case however, was somehow a growing trend among rural Chinese enterprises managers to shift away from an emphasis on managing networks of interpersonal relationships and toward the adoption of competitive market behaviors.

However, these obstacles have become an issue since none of these obstacles have been vigorously examined either empirically or theoretically so far as we knew. Some researchers' works have been made and with priority on the part where clearly underlies the complexity of the assessment question. In terms of indicators, Vesper and Gartner (1997) have identified at least 18 criteria for assessing the entrepreneurship teaching programs. Where, Block and Stumpf (1992), come up with a complicated measure which was due to the existence of late effects. However, the field of entrepreneurship teaching programs/courses is very diversified and heterogeneous, depending on the intending learning and teaching objectives, the audiences, the contents, the teacher profiles, the pedagogical methods and approaches, etc.

This paper tries to look into the possibility of how could avoid these difficulties by reconsidering and reformulating the measurements and assessment questions. It seems that the most important result of any entrepreneurship teaching programs/courses is not necessarily the creation of start-ups, but could be among students' mindset changes, attitude changes, and the development of entrepreneurial orientation, measured through intentions. However, entrepreneurship education in particular focuses on giving students awareness of an entrepreneurial mindset and capability, all of which are prerequisites for entrepreneurial effectiveness (Fayolle, 2003).

Universities are already started to adopt several new methods in their curriculums related to the entrepreneurial topic in early stages with the hope to find a good way to produces entrepreneurial; curses have been modified, seminars, workshops, etc., it is a useful strategy to confront demographic pressures and youth unemployment, since it provides the youth with knowledge and competencies that empower them to face socio-economical challenges and changes throughout their lives. It is closely associated with the promotion of human development and social justice in vulnerable communities, and it is expected that entrepreneurship education and training helps people to engage in decent income-generating activities that can lead them out of poverty and towards sustainable livelihoods.

The Bahraini higher education lunched in its national higher education report reported that; "the higher education central have to perform a critical role in terms of addressing the skills needs of the workforce of tomorrow by improving 
overall quality, skills, entre entrepreneurship and technology" (HEC, 2014). The strategy's main guiding themes are "quality enhancement", "skills for the future", "strategic access", becoming a regional hub for higher education, technology in education and "entrepreneurship" (HEC, 2014).

Although, Bahrain considered to be the first Arab state has introduced entrepreneurship education within the curriculum of secondary education in 1998 within the textbooks of (Industrial Relations) which targeted students of formal and informal education and reviewed in 2002 (Lamloumi, 2013); but, it is early to evaluate the entrepreneurship education in Bahrain, where it is still at its basic level, offered in an uncoordinated manner and lacking strong support and integration across levels and curriculum (HEC, 2014). Therefore, it is worthy to investigate to what extent this curriculum which been offered in Bahraini universities goes along with the Bahraini higher education council visions' which hoped to achieve their strategy and entrepreneurship ecosystem in Bahrain?. Though the entrepreneurship ecosystem is by no means related strictly to higher education, the latter can play a pivotal role in guiding young Bahrainis into new businesses and activities. However, the higher education level, the greater success could be achieved, which is due to the fact that college gives people additional skills that can be used within their business and to operate on a higher level than someone who only "runs" it (Michelacci \& Schivardi, 2020). In summary of a few related studies indicated several challenges facing women who are trying to set up their own businesses. These challenges, include the lack of or weak skills required for managing economic activities, the lack of or weak education and training, the weak self-confidence and stereotypes of women as not being expected to be independent owners of businesses (Alajami \& Alsaleh, 2011).

However, although of great effort concern this issue, still there is a lack of research regarding the Arab world. Planed behavior theory is used in highlighting and understanding the entrepreneurship characteristics and its impact on entrepreneurial intentions.

\section{Study Objectives}

This paper turns to the achievement of certain transformative results, namely, Attitude toward the Behavior, Subjective Norm and Perceived Behavioral Control and their impacts on Intention on Behavioral entrepreneur by answering the following questions, which is driving the problem of this research:

1) What are the relationship effect of Subjective norm, Perceived behavioral control, Attitude toward the behavior, on the personal behavioral Intention of entrepreneur?

2) To what extent Planned Behavior Theory measures the entrepreneurs' intentions?

3) What are the characteristics should entrepreneurs have?

4) Do institutions pay enough attention to innovation to achieve entrepreneurship? 


\section{Literature Review}

Research on entrepreneurship in transition economies has been increasing in recent years. A distinctive feature of entrepreneurship in transition economies is that; its determinants and route to success are largely shaped by socially and institutionally regulated environments (Kodithuwakku \& Rosa, 2002; Peng \& Shekshnia, 2001). The formal institutional constraints are various and some could be the market infrastructure of professional, state control mechanisms or as it appears as regulatory authorities, and government agencies, etc. ... these elements have been recognized as inhibiting forces for reformed state-owned enterprises and non-state-owned enterprises such as the private enterprises for example, alike to seek growth opportunities through market-driven entrepreneurship.

Instead, Peng (2001) reported that social entrepreneurship seems to have the potential to compensate for underdeveloped institutional structures in some countries. It is a complex concept, and the social entrepreneurship definition and conceptual domain remain ambiguous somehow. Part of the reason is that the phenomenon has been studied from a variety of perspectives such as economics, sociology, and strategic management (Jack \& Anderson, 2002; McDougall \& Oviatt, 2000). In general, social entrepreneurship is conceptualized as an expression of entrepreneurial behavior to achieve a social mission and to benefit the community or society (Sullivan Mort et al., 2003).

In spite of what had been mentioned above, Matsuno et al. (2002) suggested that the conceptual area of entrepreneurship may involve market-driven entrepreneurial management processes, which is more related to strategic management and entrepreneurship literature. An organizational predisposition to entrepreneurial management processes is manifested through three underlying dimensions: innovativeness, risk-taking, and proactiveness (e.g. Covin \& Slevin, 1989).

Social entrepreneurship comprises social and institutional embeddedness with respect to market-oriented entrepreneurial conduct or attitude; however, entrepreneurship takes place through an organization's commitment to market orientation, so this would bring together the unique organizational-specific resources in order to exploit marketplace opportunities, social entrepreneurship asserts the role of social and institutional determinants in shaping and sustaining the entrepreneurial process.

According to study conducted by Kelley, Singer, \& Herrington (2016), the entrepreneurs in 122 economies showed improvements in their local regulatory framework (Kelley et al., 2016). Moreover, between June 2014 and June 2015, the study reported, which measures 189 economies worldwide, documented 231 business reforms. Among reforms to reduce the complexity and cost of regulatory processes, those in the area of starting a business were the most common in $2014 / 15$, as in the previous year. The next most common were reforms in the areas of paying taxes, getting electricity and registering property (Kelley et al., 2016). 
The Arab countries are in humble rank on the list of ease of doing business, it is very important to consider these facts (World Bank, 2020b). The data extracted from reliable resources are displayed in Figure 1 and Table 1.

Table 1 is created to demonstrate the ease of doing business score based on data collected and studied by the World Bank.

According to the World Bank (2020b) report, these economies are ranked on their ease of doing business, from 1 - 191 countries. It shows the highest ease of conducting business rank in the studied populations, it refers to the regulatory environment which is more conducive to the starting and operation of a local firm.

Bahrain is ranked in the highest ranks among the Arab countries after the United Arab Emirates. This could be explained by how these governments succeed in putting a lot of effort into encouraging their citizens by helping them in many different aspects and methods not only in schooling them but beyond that. Perhaps, ease of registration and dealing with construction permits issues, open environment towards internationalization so on, will help those entrepreneurs.

These producers would help in developing and encouraging the new ideas, so for those entrepreneurs, they will easily have the chance to reach and conduct their business.

Some successful Business and Entrepreneurship education institutions worldwide, such as Stanford University, Massachusetts Institute of Technology (Sloan), Harvard University and University of Michigan, Ann Arbor (Ross) a unique school, dedicated themselves to providing quality education in entrepreneurial and business leadership in different places in the world. Although big business is vital for economic health and prosperity, a strong cadre of SMIs and SMEs is also essential to ensure a diverse economy and to provide the required support to big business and the community. Table 1 was created for a better understanding of ease of doing business score based on economy (countries) based on data provided by World Bank (2020b). The list shows that New Zealand scoring the easiest country in terms of ease of doing business, however, the Arab countries have different rankings based on the WB report.

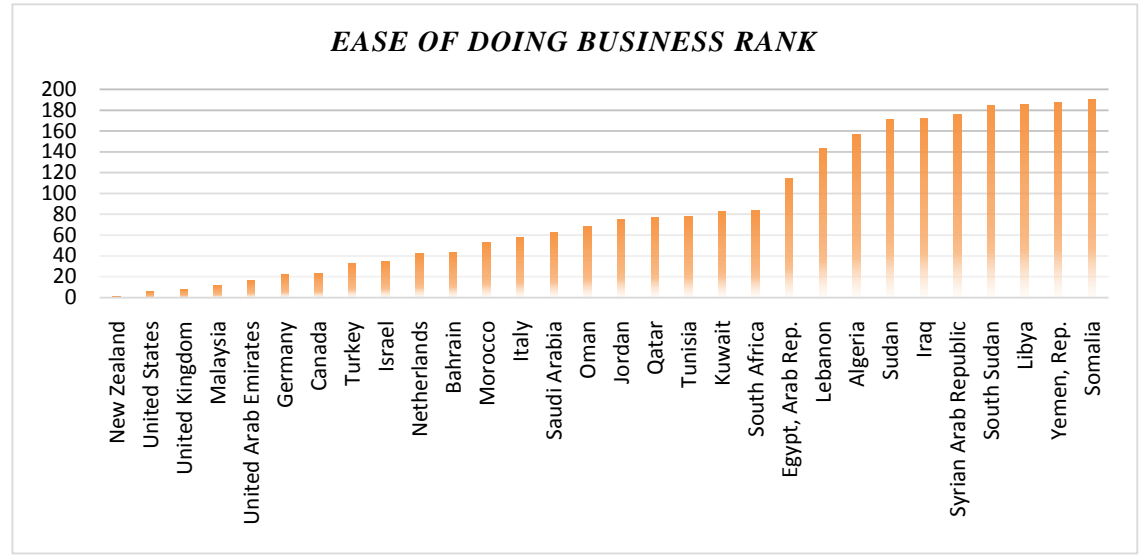

Figure 1. Ease of doing business rank. Source: World Bank (2020b). 
Table 1. Ease of doing business score.

\begin{tabular}{|c|c|c|c|c|c|c|c|c|}
\hline Economy & $\begin{array}{c}\text { Ease of Doing } \\
\text { Business Rank } \\
\text { Global Rank }\end{array}$ & $\begin{array}{c}\text { Dealing with } \\
\text { Construction } \\
\text { Permits }\end{array}$ & $\begin{array}{c}\text { Getting } \\
\text { Electricity }\end{array}$ & $\begin{array}{c}\text { Registering } \\
\text { Property }\end{array}$ & $\begin{array}{c}\text { Getting } \\
\text { Credit }\end{array}$ & $\begin{array}{l}\text { Protecting } \\
\text { Minority } \\
\text { Investors }\end{array}$ & $\begin{array}{c}\text { Paying } \\
\text { Taxes }\end{array}$ & $\begin{array}{c}\text { Trading } \\
\text { across } \\
\text { Borders }\end{array}$ \\
\hline New Zealand & 1 & 7 & 48 & 2 & 1 & 3 & 9 & 63 \\
\hline United States & 6 & 24 & 64 & 39 & 4 & 36 & 25 & 39 \\
\hline United Kingdom & 8 & 23 & 8 & 41 & 37 & 7 & 27 & 33 \\
\hline United Arab Emirates & 16 & 3 & 1 & 10 & 48 & 13 & 30 & 92 \\
\hline Germany & 22 & 30 & 5 & 76 & 48 & 61 & 46 & 42 \\
\hline Canada & 23 & 64 & 124 & 36 & 15 & 7 & 19 & 51 \\
\hline Turkey & 33 & 53 & 41 & 27 & 37 & 21 & 26 & 44 \\
\hline Israel & 35 & 35 & 83 & 75 & 48 & 18 & 13 & 67 \\
\hline Netherlands & 42 & 88 & 58 & 30 & 119 & 79 & 22 & 1 \\
\hline Bahrain & 43 & 17 & 72 & 17 & 94 & 51 & 1 & 77 \\
\hline Morocco & 53 & 16 & 34 & 81 & 119 & 37 & 24 & 58 \\
\hline Italy & 58 & 97 & 38 & 26 & 119 & 51 & 128 & 1 \\
\hline Saudi Arabia & 62 & 28 & 18 & 19 & 80 & 3 & 57 & 86 \\
\hline Oman & 68 & 47 & 35 & 52 & 144 & 88 & 11 & 64 \\
\hline Jordan & 75 & 138 & 69 & 78 & 4 & 105 & 62 & 75 \\
\hline Qatar & 77 & 13 & 49 & 1 & 119 & 157 & 3 & 101 \\
\hline Tunisia & 78 & 32 & 63 & 94 & 104 & 61 & 108 & 90 \\
\hline Kuwait & 83 & 68 & 66 & 45 & 119 & 51 & 6 & 162 \\
\hline South Africa & 84 & 98 & 114 & 108 & 80 & 13 & 54 & 145 \\
\hline Egypt, Arab Rep. & 114 & 74 & 77 & 130 & 67 & 57 & 156 & 171 \\
\hline Lebanon & 143 & 164 & 127 & 110 & 132 & 114 & 116 & 153 \\
\hline Algeria & 157 & 121 & 102 & 165 & 181 & 179 & 158 & 172 \\
\hline Sudan & 171 & 124 & 162 & 95 & 176 & 153 & 164 & 185 \\
\hline Iraq & 172 & 103 & 131 & 121 & 186 & 111 & 131 & 181 \\
\hline Syrian Arab Republic & 176 & 186 & 160 & 162 & 176 & 97 & 91 & 178 \\
\hline South Sudan & 185 & 171 & 187 & 177 & 181 & 185 & 74 & 180 \\
\hline Libya & 186 & 186 & 142 & 187 & 186 & 183 & 130 & 129 \\
\hline Yemen, Rep. & 187 & 186 & 187 & 86 & 186 & 162 & 89 & 188 \\
\hline Somalia & 190 & 186 & 187 & 153 & 186 & 190 & 190 & 166 \\
\hline
\end{tabular}

Source: World Bank (2020a). 
However, United States, Switzerland, Canada as well as United Kingdom remaining to be on the top list of the world entrepreneur's countries (World Bank, 2020a). Table 2 was created for a better understanding of the top world entrepreneur's countries according to the World Bank 2020.

According to study conducted by World Bank (2020b) Group in regard to doing business in the Arab world. The study reported that, the Middle East countries and North Africa region has implemented the most reforms on record to ease doing business for domestic small and medium-sized enterprises and hosted four of the countries that improved the most world-wide (World Bank, 2020b).

The Middle East Economies especially the Gulf countries have shown an active status in particular, where there had implemented 35 business-climate-improving measures in the past year. However, it is worthy to mention that there were four economies rising slightly quickly in a couple of years recently, the region hosts four of the world's top 10 improvers, which as listed below:

1) Saudi Arabia.

2) Jordan.

3) Bahrain.

4) And Kuwait.

Where the United Arab Emirates still continued to record the highest and the strongest performer overall in the region, placing $16^{\text {th }}$ (out of 191) on the ease of doing business rankings as stated earlier. This has been confirmed by Ferid Belhaj World Bank Regional Vice President for the Middle East and North Africa, he reported that "It is a year of records for economies in the Middle East and North Africa, and we are committed to continuing our support to all countries in the region". "The next generation of reforms should focus on transparency, fair competition and good governance to make MENA open for business and attract investments needed to create jobs for youth and women." Figure 2 was created to display the top Arabs' Entrepreneurs countries according to the World Bank (2020b).

Table 2. The top world entrepreneurs countries according to the World Bank 2020.

\begin{tabular}{cccc}
\hline Rank & Country & GDP World Bank international\$2011 & GEI \\
\hline 1 & United States & 52,676 & 83.6 \\
2 & Switzerland & 54,933 & 80.4 \\
3 & Canada & 42,104 & 79.2 \\
4 & United Kingdom & 37,451 & 77.8 \\
5 & Australia & 42,149 & 75.5 \\
6 & Denmark & 44,005 & 74.3 \\
7 & Iceland & 34,541 & 74.2 \\
8 & Ireland & 42,012 & 73.7 \\
9 & Sweden & 45,533 & 73.1 \\
10 & France & 37,948 & 68.5 \\
\hline
\end{tabular}

Source: World Bank (2020a). 


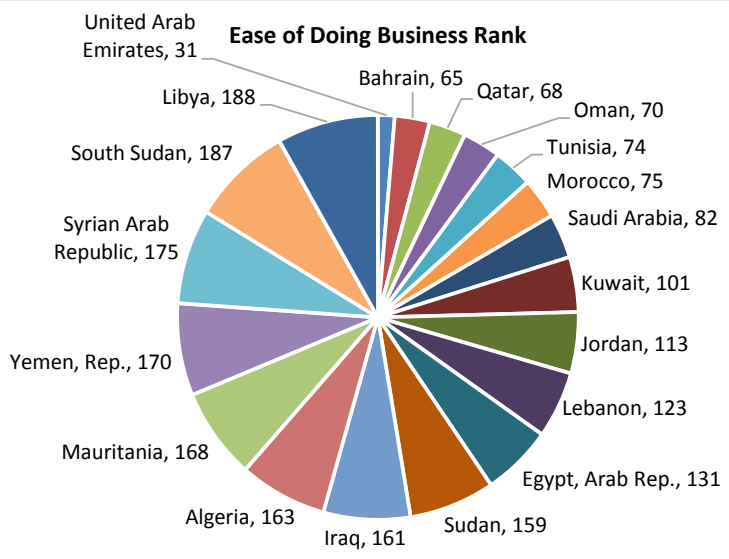

Figure 2. The top Arabs' Entrepreneurs countries according to the World Bank (2020b).

\section{Research Methodology}

The study aimed to achieve the intended objective by adopting the quantitative approach. The quantitative method was applied to collect the targeted sample size through questionnaires. The questionnaire was designed based on the related literature to this study (Omar et al., 2016). Theories and related literature were reviewed in trying to examine the personal behavioral intention of becoming an entrepreneur.

\subsection{Theory of Reasoned Action}

To achieve the attending study objectives, the theory of reasoned action was adopted, this theory has been widely used to predict behavioral intention toward people related behaviors. The theory has been reported as a valid theory to identify the people either customers, staff, or workers (Omar \& Abdul Ghani, 2016).

Similar to Fishbein et al. (1980) theory, Miniard and Cohen (1983) have also come up with a model proposed that is designed to predict behavioral intention. This model is similar insomuch in terms of the model structure to the theory of reasoned action but has important theoretical and operational differences. The present research investigates and measuring the entrepreneurship characteristics and its impact on entrepreneurial intentions. The results offer support for the independent effects of personal and normative influences in corroborate previous findings pertaining to crossover effects in the theory of reasoned action.

The behavioral intention is hard to be identified as it is regarding the individual feeling and intentions. It has been defined by Swan and Trawick (1981) as an individual's planned future behavior, which is really hard to measure. However, Ajzen \& Fishbein (1977), and Ajzen (2002) have been associated with observed behavior based on three constructs, namely Attitude, Subjective Norm, and Perceived Behavioral Control. However, the literature is the reach of several studies and theories which have been addressing the behavior intention in different aspects (Vallerand et al., 1992; Ajzen, 1991; Ajzen \& Madden, 1986; Ajzen, 1985; 
Netemeyer \& Bearden, 1992).

However, the intention of the behavior is assumed to be an indication of customers' behavior which can be as consequences of attitude based behavior. Zeithaml, Berry and Parasuraman (1996), recommended behavioral intentions to be indicators, which showed whether customers had remained with or had defected from the organization. Hence, the concept of behavioral intention is a vital part of the model. However, Zeithaml et al. (1996) suggested that favorable behavioral intentions included elements such as telling positive things and proposing the services/products to others, paying the price premium to the company and expressing cognitive loyalty to the organization. Where, cognitive loyalty has been operationalized as the service that first comes to one's mind when making a purchase decision and the service, which was a customer's first choice among alternatives (Bloemer, de Ruyter, \& Wetzels, 1998; Pritchard et al., 1992).

Although, there are a lot of efforts related in the literature investigating the relationship between service quality dimensions and the multi-dimensional model of behavioral intention, still, there is a need to adequately investigated in the behavioral intention literature (Baker \& Crompton, 2000; Bloemer et al., 1998).

As a matter of fact, these suggestions left the door open and have generated a new call for research. Still, there is little empirical research demonstrating the importance of the behavioral intention to predict individual behavioral intention especially when it comes to Measuring the Entrepreneurship Characteristics and its Impact on Entrepreneurial Intentions (Baker \& Crompton, 2000; Bloemer et al., 1998). Figure 3 was created for better understanding of the study framework.

\subsection{Data Collection and Analysis}

The primary data collected through the quantitative approach using a structured questionnaire design would be most suitable and appropriate when SEM (PLS) is used as the main method of analysis (Hair Jr. et al., 2010). Therefore, a quantitative research design is appropriate for this study. For the current study, the original questionnaire comprises four pages divided into three parts: part one comprises the cover letter, second part comprises several general questions (e.g. study level, knowledge of starting new business and so on), and third part comprises the studys' variables.

However, the final part is divided into five questions relating to the respondents' general demographic profile measured by nominal and ordinal scales like gender, age, income, occupation and education.

Accordingly, a total of 1000 questionnaires were distributed in this study. All graduated and post-graduate students were targeted to receive their feedback by answering the designed questionnaire. The designed questionnaire contains some open and open-ended questions. The participant was asked to answer all 


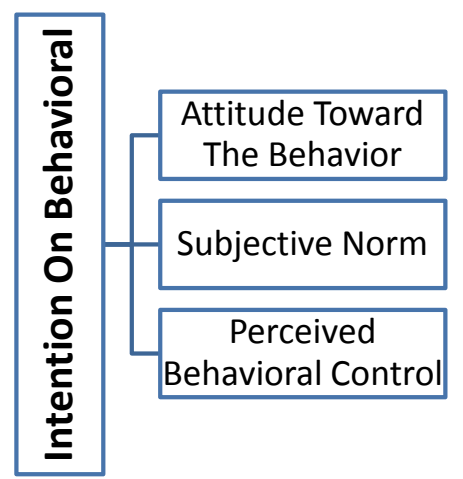

Figure 3. Research framework.

the questions. Using these procedures, 945 questionnaires were returned, indicating a $94.5 \%$ rate of return. The final count valid questionnaires for this study were 930, perhaps after excluding missing data, outliers, and incomplete questionnaires.

For data analyses, the study adopted two-step procedure in order to analyze the optioned data. However, examined the measurement model to measure reliability and validity was the first step following by examined the structural model to investigate the strength and direction of the relationships among the theoretical constructs.

The conceptual framework was set and confirmatory factor analysis (CFA) using SmartPlS for the measurement of the study model, which is a technique used in order to test the measurement model. The measurement model was examined and suggested to be a fit model and the sample data well. The reliability and discriminant validity of the constructs were estimated by Cronbach alpha, composite reliability and average variance extracted, respectively, as shown in Table 3. For better understating of the conceptual framework, Figure 4 shows the research conceptual framework (measurement model) as below:

Cronbach alpha, composite reliability and average variance extracted, respectively, as shown in Table 3.

Table 3 shows Cronbach alpha, composite reliability and average variance extracted, respectively.

Grounded on the results shown in Table 4, the results show that all the purposed hypothesis subjective norm, attitude and perceived behavioral control $P$-value have a significant positive influence on the behavioral intention with ( $P$ $\left.<0.001^{* * *}\right)$. Hence, the regression weight for Subjective Norm, Attitude and Perceived Behavioral Control in the prediction of the personal behavioral Intention of entrepreneur is significantly different from zero at 0.001 level (two-tailed). In this case Subjective Norm, Attitude and Perceived Behavioral Control have a significant direct effect prediction of the personal behavioral Intention of entrepreneur is therefore, $\mathrm{H} 1, \mathrm{H} 2$ and $\mathrm{H} 3$ are supported.

Figure 5 and Figure 6 display the Construct Reliability and Validity results of the study's variables. 


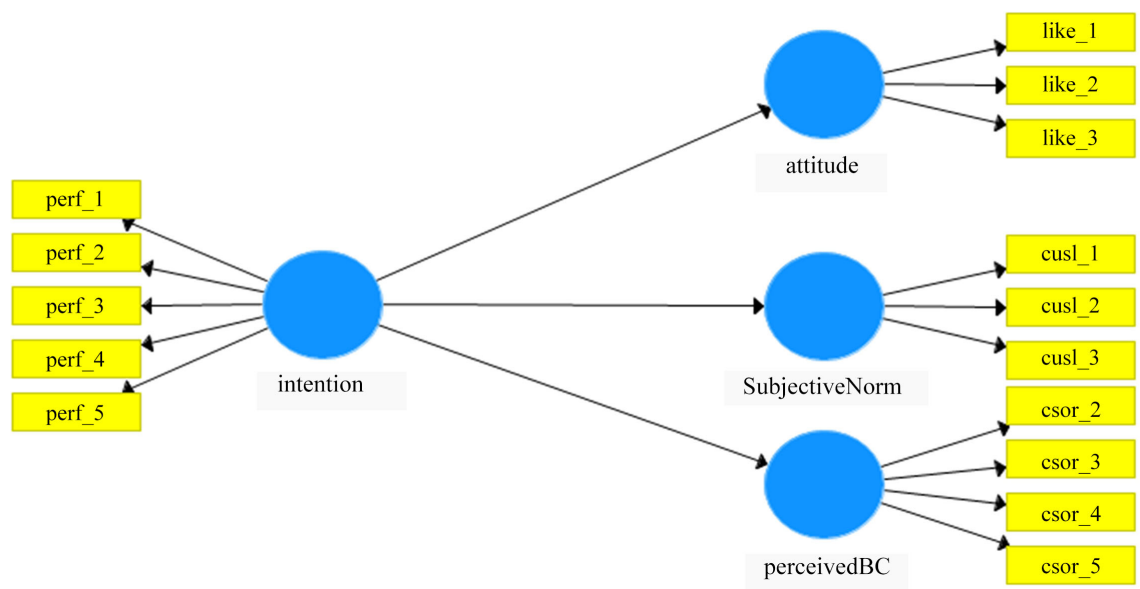

Figure 4. Research conceptual framework:

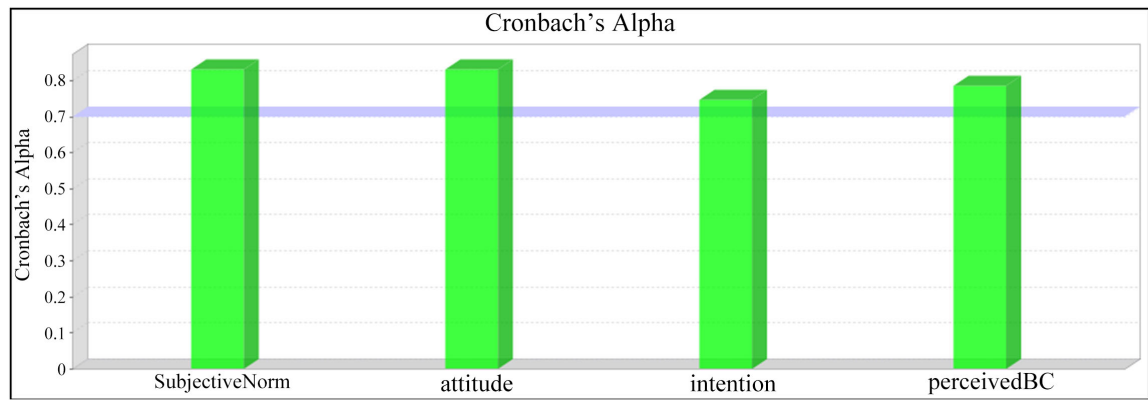

Figure 5. Construct reliability and validity.

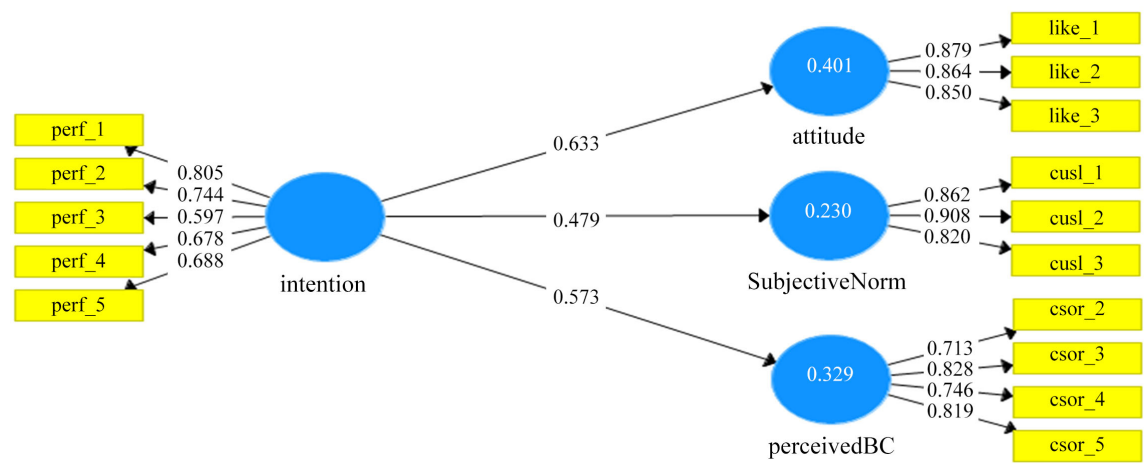

Figure 6. Construct reliability and validity.

Table 3. Construct reliability and validity.

\begin{tabular}{ccccc}
\hline & $\begin{array}{c}\text { Cronbach's } \\
\text { Alpha }\end{array}$ & rho_A & $\begin{array}{c}\text { Composite } \\
\text { Reliability } \\
\text { (CR) }\end{array}$ & $\begin{array}{c}\text { Average } \\
\text { Variance } \\
\text { Extracted (AVE) }\end{array}$ \\
\hline Subjective Norm & 0.831 & 0.845 & 0.898 & 0.747 \\
Attitude Toward The Behavior & 0.831 & 0.835 & 0.899 & 0.747 \\
Intention On Behavioral & 0.747 & 0.768 & 0.831 & 0.498 \\
Perceived Behavioral Control & 0.786 & 0.812 & 0.859 & 0.605 \\
\hline
\end{tabular}


Table 4. Hypotheses results.

\begin{tabular}{|c|c|c|c|c|c|c|}
\hline & Hypotheses & Original & Sample & Standard & $\mathrm{T}$ & $P$ \\
\hline H1 & Intention ->Subjective Norm & 0.479 & 0.482 & 0.046 & 10.316 & 0.000 \\
\hline $\mathrm{H} 2$ & Intention -->Attitude & 0.633 & 0.637 & 0.036 & 17.380 & 0.000 \\
\hline H3 & $\begin{array}{c}\text { Intention ---> Perceived } \\
\text { Behavioral Control }\end{array}$ & 0.573 & 0.578 & 0.037 & 15.593 & 0.000 \\
\hline
\end{tabular}

\section{Conclusion and Discussion}

This present paper suggests a framework of entrepreneurship for the postgraduate entrepreneurial firms in the transitional market economy of Bahrain. The framework highlights both institutional and social determinants and consequences of market orientation in regard to entrepreneurship.

It is a fact that entrepreneurship becomes essential for the development of any economy. The success of many countries is linked to their progress and growth in entrepreneurship. Therefore, this matter no longer only remains of the interests of the person but also states and their governments must be aware of this matter greatly. The governments and people all over the world have to encourage the government's buddies on this concept. The paper focused on the factors that impact entrepreneurship development with special attention to the importance of Measuring Entrepreneurship Characteristics.

The study achieves its objectives by answering the research questions. The results confirmed that entrepreneurs' characteristics of intention are affected by several variables. The theory of reasoned action is a valid theory for measuring the entrepreneurs' characteristics of intention. However, subjective norm, attitude, and perceived behavioral control were found to have a positive effect on entrepreneurs' intention. This, however, would open the door for future research related to the characteristics and capabilities of entrepreneurial success, such an interesting opportunity for further research will help in drawing a clear picture on entrepreneurial success characteristics needed.

Perhaps, by identifying the significant predictors of growth, abilities, and so on, the decision makers such as government authorities as well as the education experts and advisors, would focus on this when stimulating entrepreneurship.

However, gulf countries (GCC) region is a promising area for new entrepreneurial born, where the governments try through their governmental visions and plan to have new strategies for alternatives sources instant of the traditional economic methods of incomes. This was approved by the results shown in the World Bank (2020b) reports. However, it is not yet clear if the entrepreneurial ecosystem is a useful concept for all regions. Perhaps, it is appropriate only for regions which already have a critical mass of new firms (Poon et al., 2009). 


\section{Conflicts of Interest}

The author declares no conflicts of interest regarding the publication of this paper.

\section{References}

Ajzen, I. (1991). The Theory of Planned Behavior. Organizational Behavior and Human Decision Processes, 50, 179-211. https://doi.org/10.1016/0749-5978(91)90020-T

Ajzen, I. (2002). Perceived Behavioral Control, Self-Efficacy, Locus of Control, and the Theory of Planned Behavior. Journal of Applied Social Psychology, 32, 665-683. https://doi.org/10.1111/j.1559-1816.2002.tb00236.x

Ajzen, I., \& Fishbein, M. (1977). Attitude-Behavior Relations: A Theoretical Analysis and Review of Empirical Research. Psychological Bulletin, 84, 888-918. https://doi.org/10.1037/0033-2909.84.5.888

Ajzen, I., \& Madden, T. J. (1986). Prediction of Goal-Directed Behavior: Attitudes, Intentions, and Perceived Behavioral Control. Journal of Experimental Social Psychology, 22, 453-474. https://doi.org/10.1016/0022-1031(86)90045-4

Ajzen, L. (1985). From Intentions to Actions: A Theory of Planned Behavior. In J. Kuhl, \& J. Beckmann (Eds.), Action Control. SSSP Springer Series in Social Psychology (pp. 11-39). Berlin, Heidelberg: Springer.

Alajami, J., \& Alsaleh, N. (2011). Training for Women Entrepreneurs in Managing Micro, Small- and Medium-Sized Enterprises. Views of Participants. Supreme Council for Women.

Baker, D. A., \& Crompton, J. L. (2000). Quality, Satisfaction and Behavioral Intentions. Annals of Tourism Research, 27, 785-804. https://doi.org/10.1016/S0160-7383(99)00108-5

Block, Z., \& Stumpf, S. A. (1992). Entrepreneurship Education Research: Experience and Challenge. In Sexton D. L., \& Kasarda J. D. (Eds.), The State of the Art of Entrepreneurship (pp. 17-42). USA: PWS-Kent Publishing Company.

Bloemer, J. Â., de Ruyter, K., \& Wetzels, M. (1998). Linking Perceived Service Quality and Service Loyalty: A Multi-Dimensional Perspective. European Journal of Marketing, 33, 1082-1106. https://doi.org/10.1108/03090569910292285

Covin, J. G., \& Slevin, D. P. (1989). Strategic Management of Small Firms in Hostile and Benign Environments. Strategic Management Journal, 10, 75-87. https://doi.org/10.1002/smj.4250100107

de Beurs, S. (2018). Guide for Mapping the Entrepreneurial Ecosystem. Washington DC: Aspen Institute.

Fayolle, A. (2003). Le métier de créateur d;entreprise. Ed. D’Organisation.

Fayolle, A., \& Gailly, B. (2004). Using the Theory of Planned Behaviour to Assess Entrepreneurship Teaching Programs: A First Experimentation. 14th Annual IntEnt Conference, Italy, 4-7 July 2004, 5-7.

Fishbein, M., Jaccard, J., Davidson, A. R., Ajzen, I., \& Loken, B. (1980). Predicting and Understanding Family Planning Behaviors. In Understanding Attitudes and Predicting Social Behavior. Englewood Cliffs, NJ: Prentice Hall.

Fuerlinger, G., Fandl, U., \& Funke, T. (2015). The Role of the State in the Entrepreneurship Ecosystem: Insights from Germany. Triple Helix, 2, 1-26.

https://doi.org/10.1186/s40604-014-0015-9 
Hair Jr., J. F., Black, W. C., Babin, B. J., \& Anderson, R. E. (2010). Multivariate Data Analysis: A Global Perspective (7th ed.). Upper Saddle River, NJ: Pearson Education Inc.

Higher Education Council HEC (2014). National Higher Education Strategy.

Jack, S. L., \& Anderson, A. R. (2002). The Effects of Embeddedness on the Entrepreneurial Process. Journal of Business Venturing, 17, 467-487. https://doi.org/10.1016/S0883-9026(01)00076-3

Kelley, D., Singer, S., \& Herrington, M. (2016). Global Entrepreneurship Monitor 2015/16 Global Report.

Kodithuwakku, S. S., \& Rosa, P. (2002). The Entrepreneurial Process and Economic Success in a Constrained Environment. Journal of Business Venturing, 17, 431-465. https://doi.org/10.1016/S0883-9026(01)00074-X

Lamloumi, J. (2013). Entrepreneurship Education in the Arab States. Final Evaluation Report, UNESCO-UNEVOC International Centre for Technical and Vocational Education and Training.

Malecki, E. J. (2018). Entrepreneurship and Entrepreneurial Ecosystems. Geography Compass, 12, e12359. https://doi.org/10.1111/gec3.12359

Matsuno, K., Mentzer, J. T., \& Özsomer, A. (2002). The Effects of Entrepreneurial Proclivity and Market Orientation on Business Performance. Journal of Marketing, 66, 18-32. https://doi.org/10.1509/jmkg.66.3.18.18507

McDougall, P. P., \& Oviatt, B. M. (2000). International Entrepreneurship: The Intersection of Two Research Paths. Academy of Management Journal, 43, 902-906.

Michelacci, C., \& Schivardi, F. (2020). Are They All Like Bill, Mark, and Steve? The Education Premium for Entrepreneurs. Labour Economics, 67, Article ID: 101933.

Miniard, P. W., \& Cohen, J. B. (1983). Modeling Personal and Normative Influences on Behavior. Journal of Consumer Research, 10, 169-180. https://doi.org/10.1086/208957

Netemeyer, R. G., \& Bearden, W. O. (1992). A Comparative Analysis of Two Models of Behavioral Intention. Journal of the Academy of Marketing Science, 20, 49-59.

https://doi.org/10.1007/BF02723475

OECD Local Economic and Employment Development Programme in collaboration with the Danish Business Authority (2013). An International Benchmarking Analysis of Public Programmes for High-Growth Firms. Paris: OECD Publications.

Omar, K. M., \& Abdul Ghani, A. H. (2016). The Interaction Effect of Religious' Obligations between the Relationship of CARTER Model and the Intention to Subscribe the Islamic Banking in Libya. International Business Management, 10, 759-777.

Omar, K., Kamariah, N., Mat, N., Imhemed, G. A., Mahdi, F., \& Ali, A. (2016). The Direct Effects of Halal Product Actual Purchase Antecedents among the Direct Effects of Halal Product Actual Purchase Antecedents among the International Muslim Consumers. American Journal of Economics, 2, 87-92.

Peng, M. W. (2001). The Resource-Based View and International Business. Journal of Management, 27, 803-829. https://doi.org/10.1177/014920630102700611

Peng, M. W., \& Shekshnia, S. V. (2001) How Entrepreneurs Create Wealth in Transition Economies. The Academy of Management Executive, 15, 95-111. https://doi.org/10.5465/ame.2001.4251397

Poon, P. S., Zhou, L., \& Chan, T. (2009). Social Entrepreneurship in a Transitional Economy: A Critical Assessment of Rural Chinese Entrepreneurial Firms. Journal of Management Development, 28, 94-109. https://doi.org/10.1108/02621710910932061 
Pritchard, M. P., Howard, D. R., \& Havitz, M. E. (1992). Loyalty Measurement: A Critical Examination and Theoretical Extension. Leisure Sciences: An Interdisciplinary Journal, 14, 155-164. https://doi.org/10.1080/01490409209513164

Roberts, E. B., \& Eesley, C. (2009). Impact: The Role of MIT.

Sullivan Mort, G., Weerawardena, J., \& Carnegie, K. (2003). Social Entrepreneurship: towards Conceptualisation. International Journal of Nonprofit and Voluntary Sector Marketing, 8, 76-88. https://doi.org/10.1002/nvsm.202

Swan, J. E., \& Trawick, I. F. (1981). Swan Expectations and Satisfaction. Journal of Retailing, 57, 49-67.

Vallerand, R. J., Deshaies, P., Cuerrier, J.-P., \& Pelletier, L. (1992). Ajzen and Fishbein's Theory of Reasoned Action as Applied to Moral Behavior: A Confirmatory Analysis. Journal of Personality and Social Psychology, 62, 89-109. https://doi.org/10.1037/0022-3514.62.1.98

Vesper, K. H., \& Gartner, W. B. (1997). Measuring Progress in Entrepreneurship Education. Journal of Business Venturing, 12, 403-421. https://doi.org/10.1016/S0883-9026(97)00009-8

World Bank (2020a). Doing Business 2020: Comparing Business Regulation in 190 Economies. Washington DC: World Bank. https://openknowledge.worldbank.org/handle/10986/32436

World Bank (2020b). Doing Business 2020: Four Arab Countries among World's Top 10 Business Climate Improvers. Washington DC: World Bank. https://www.worldbank.org/en/news/press-release/2019/10/24/doing-business-2020-fo ur-arab-countries-among-worlds-top-10-business-climate-improvers

Zeithaml, V. A., Berry, L. L., \& Parasuraman, A. (1996). The Behavioral Consequences of Service Quality. Journal of Marketing, 60, 31-46.

https://doi.org/10.1177/002224299606000203 